moci. Nesplnění podmínek právního řádu pro uzavření manželství rodičů by mělo být v tomto př́padě $\mathrm{v}$ podstatě irelevantní. Takto fungující rodina by totiž splňovala i onen prapůvodní charakter manželství, jakožto smlouvy mezi mužem a ženou o společném životě.

Zajímavou, relevantní a inspirující se jeví i pasáž z Lexikonu o právech rodiny a lidských právech (viz výše). Zdá se, že tendence intenzivního posilování práv jedince s sebou prínáší oslabování vazby jednotlivce na společenství, v němž žije. Práva každého jednotlivce, ostatně $\mathrm{i}$ jeho povinnosti, lze definovat pouze $\mathrm{v}$ jeho vztazích vůči svému okolí. Čím intenzivněji posiluji práva jedince, tím větší bariéru vytvárím mezi ním a jeho okolím. Posilováním postavení jednotlivce tak v podstatě atomizuji společenství, v němž žije. Možná i zamyšlení se nad tren- dy v neustálém rozšiřování katalogu práv člověka jako individua (dítěte, žen, př́slušníků menšin apod.) by mohlo pomoci prri hledání cesty, jak pomoci a jak chránit tu nejzákladnější stavební jednotku lidského společenství. Kdo ví, možná posílení její ochrany by v konečném důsledku vedlo k posílení ochrany nejzranitelnějších členů lidského rodu. Jsem si dobře vědom problému vytváření kategorie kolektivních práv, kam by práva rodiny patřila, na druhou stranu by možná právě tato cesta $\mathrm{v}$ konečném důsledku mohla vést i k posílení ochrany individuálních práv některých kategorií, mám na mysli především děti, a možná dokonce i efektivnějším způsobem nežli dosud. Jenže tímto se opět vracíme na začátek, a to k problému absence právní definice rodiny, jak správně upozorňuje JUDr. Attl.

JUDr. Pavel Vošalik

\section{NĚKOLIK POZNÁMEK K ČLÁNKU (vyjádření autora $\mathrm{k}$ recenzím)}

Výše jmenovaný článek, který jsem zpracoval $\mathrm{v}$ rámci doktorského studia na Zdravotně sociální fakultě Jihočeské univerzity v Českých Budějovicích, recenzovali paní doc. JUDr. Senta Radvanová, CSc., a pan JUDr. Pavel Vošalík.

Oběma recenzentům bych chtěl poděkovat za péči, kterou obsahu mého článku věnovali, za kladná stanoviska i za připomínky či výhrady; plyne $z$ nich pro mé jistota, že jsem zvolil téma aktuální a zároveň významné.

Jestliže jsem se vúvodu článku zmínil v maximální stručnosti o nejčastějších současných argumentech pro tvrzení, že tradiční rodina prochází velkou krizí, učinil jsem tak jen proto, abych se v článku samotném pokusil o stručnou charakteristiku právní úpravy tradiční rodiny na sklonku rakousko-uherské monarchie z pohledu právně historického. Je třeba akcentovat, že v té době měla právní úprava rodiny za sebou více než stoleté období vývoje od pŕijetí OZO v roce 1811 do roku 1918. Mým záměrem do budoucna bylo na základě tohoto článku ukázat stěžejní změny, které pro právní úpravu rodinného práva príneslo dvacetileté období existence demokratického Československa a období dvou po něm následujících totalitních režimů. Veškerá tvrzení o současné krizi tradiční rodiny bez takové právně historické analýzy (byt' $\mathrm{v}$ mém podání jen základní a ne zcela komplexnî) postrádají dle mého názoru objektivní základ.

Oba recenzenti vyslovili souhlas se zveřejněním článku po drobných úpravách a oba se pak ve svých připomínkách vyjádřili nejen k v něm obsažené právní úpravě historické, ale nad jeho časový rámec zaujali stanoviska k aktuálním otázkám rodiny v období pozdějším, neřku-li současným. Paní doc. Radvanová poukazuje na vliv od poloviny 20. stolení přijatých mezinárodněprávních dokumentů o lidských právech a právech dětí na rodinné právo, na podstatné změny rodinného práva $\mathrm{v}$ tradičně demokratických zemích, judikaturu jejich ústavních soudů a judikaturu Evropského soudu pro lidská práva, v jejichž světle by archaická podoba Obecného zákoníku občanského v této době nemohla obstát.

Až k úplné současnosti se v podstatné části recenze vyjadřuje svými úvahami p. JUDr. Vošalík. Ta obsahuje kromě několika zcela souhlasných prvků také jeho ode mě odlišné úvahy 
o obecné úloze práva ve společnosti, což ve vztahu k tématu článku není významné. Absenci definice pojmu rodiny v platném právu rovněž považuje za velký nedostatek a v článku citovanou definici rodiny, převzatou z OZO a jejímž základem je pokrevní příbuzenství jejích prríslušníků (samozřejmě s výjimkou manželů), považuje za definici vlastně velmi moderní.

Za zásadní však nutno považovat poměrně obsáhlé odůvodněné a dle mého názoru nové názory na vzájemný vztah institutu rodiny a institutu manželství. V jejich nedostatečném vzájemném odlišování či směšování, ač nejsou synonymy, spatřuje recenzent jednu z prýćcin tvrzení o krizi tradiční rodiny. Model tradiční rodiny, jak je do současné doby pojímán, je založen na uzavření manželství a plození dětí $\mathrm{v}$ něm. Byl vytvořen katolickou církví a svědčí o přetrvávajícím vlivu této církve a její doktríny na rodinné právo i v sekularizované společnosti. Cituje v této souvislosti mj. i pasáž z projevu prezidenta republiky Václava Klause u pŕ́ležitosti nedávné návštěvy papeže Benedikta XVI. v Praze dne 26. 9. 2009, v němž hlava státu vyslovuje obavy $z$ nebezpečí rozpadu tradičních hodnot naší civilizace, mj. degradace modelu klasické rodiny a vydávání různých neprrirozených výstřelků za pokrok...

Recenze obsahuje i řadu dalších myšlenkově velmi hodnotných úvah. Domnívám se, že obě recenze $\mathrm{k}$ předmětnému článku by nemusely splnit pouze svou nezbytně nutnou úlohu a předmětná materie by se mohla stát základem pro širší diskusi o problematice rodiny a její úlohy v současné společnosti.

Manželství uzavírají a rodinu zakládají osoby ze všech sociálních skupin, a proto by seriózní diskuse o nich neměla být předem vymezována nějakými kritérii pro přístup do ní; objektivní rozsah možností mi není znám.

\section{Otázek je jistě mnoho; položení alespoň tří si neodpustím:}

1. Není do současné doby př́liš mnoho úsilí věnováno řešení následků krize tradiční rodiny oproti zkoumání jejích př́čin a jejich odstraňování?

2. Kde leži hranice mezi přirozeným uplatňováním osobních práv a svobod jednotlivce a egoismem, nejsou nékteré úvahy o poklesu významu rodiny determinovány dosaženým stupněm životní úrovně, nevzrůstal by význam rodiny včetně mezigenerační solidarity v „dobách zlých“?

3. Neškodí narůstající absolutistické pojetí těchto práv tradiční rodině a musí nám nutně vadit, že tento model tradiční rodiny vytvořila katolická církev, jsme-li v tomto geografickém prostředí bez vyznání či vyznáváme jiné náboženství? Záleží tedy více na tom, kdo určitou hodnotu vytvoril, nebo co je jejím obsahem? 